\title{
Nutritional value, phytochemicals and antioxidant property of six wild edible plants consumed by the Bodos of North-East India
}

\author{
Sanjay Basumatary ${ }^{\mathrm{a}, *}$ and Hwiyang Narzary ${ }^{\mathrm{b}}$ \\ ${ }^{a}$ Department of Chemistry, Bodoland University, Kokrajhar, Assam, India \\ ${ }^{\mathrm{b}}$ Department of Biotechnology, Bodoland University, Kokrajhar, Assam, India
}

Received 14 July 2017

Accepted 17 August 2017

\begin{abstract}
.
BACKGROUND: Plants are known to contain minerals and many bioactive compounds which provide several health benefits on consumption.

OBJECTIVE: The aim of present study was to assess the nutritional composition, phytochemical constituents and antioxidant activities of six wild edible plants consumed by the Bodos of North-East India and the plants are Sphenoclea zeylanica, Cardamine hirsuta, Natsiatum herpeticum, Sphaerantus peguensis, Melothria perpusilla, and Persicaria chinensis.

METHODS: Proximate composition of the plant was determined following AOAC method. Mineral contents were analyzed using Atomic Absorption Spectrometer. Phytochemical screening of methanol extracts were performed following standard procedures and several assays were used to evaluate the antioxidant activity of the plants.

RESULTS: The investigation showed that all the six plants have variable quantities of proximate and mineral compositions. The phytochemical screening of methanol extracts revealed the presence of a number of medicinally active secondary metabolites. Among the six wild edible plants, $M$. perpusilla displayed a better antioxidant property showing the strongest DPPH radical scavenging activity, maximum FRAP value, highest phenolic and flavonoid contents.

CONCLUSIONS: The results of this investigation indicate that these wild edible plants are good sources of minerals and natural antioxidants to be incorporated as functional ingredients of food.
\end{abstract}

Keywords: Wild edible plants, proximate composition, metals, antioxidant, North-East India

\section{Introduction}

The interest in research and development activities on wild or underutilized plant and fruit species is presently increasing throughout the world because of their positive role against various diseases [1]. Wild plants have been playing a very momentous role in human life for thousands of years. They have been used for food, medicine, fiber and other purposes and also as food for domestic animals. Wild edible plants serve as alternative to staple

\footnotetext{
${ }^{*}$ Corresponding author: Sanjay Basumatary, M.Sc., Ph.D., Department of Chemistry, Bodoland University, Kokrajhar-783370, Assam, India. Tel.: +91 9954336448; E-mail: waytosanjay12@gmail.com.
} 
food during periods of food deficit, potential source of nutrient supplements against malnutrition as well as income sources for rural communities. They have occupied a unique place as they are rich sources of essential minerals, vitamins and bioactive compounds which have several health benefits $[2,3]$.

Plants contain many phytochemicals such as alkaloids and phenolic compounds in addition to nutrients such as minerals, vitamins, proteins and carbohydrates, and several studies have shown that consumption of fruits, vegetables and plant derived food products have health benefits against chronic diseases including cardiovascular disease and certain types of cancer [3-5]. More than 900 different phytochemicals have already been identified in foods and in just one vegetable or plant food, more than 100 different phytochemicals are found to be present [6]. Many of these phytochemicals have antioxidant properties and support in protection of cells against the oxidative damage caused by reactive oxygen species [7,8]. Antioxidants are the molecules which have the ability to scavenge or inhibit the oxidation of other molecules. Oxidation reactions can generate reactive oxygen species like oxygen free radicals which initiate chain reactions that may lead to formation of unwanted products or cell damage causing many diseases such as cancer, arthritis, diabetes, and other diseases related to humans $[3,9,10]$. Phytochemicals such as polyphenols and other bioactive compounds can prevent these chain reactions by scavenging free radicals and obstruct oxidation of other biomolecules [11,12]. These phytochemicals provide endless prospects for new drug development due to the unmatched availability of chemical variety and plant derived food products are considered to be less toxic and more free from the side effects than synthetic drugs [13]. According to World Health Organization (WHO), $80 \%$ of the world's population still depends on traditional remedies for their medicines which have compounds derived from plants. The massive traditional knowledge of medicinal plants is presently playing a very essential role in the development of new drugs. Nowadays, physicians like Ayurvedic, Homoeo and Unani use various species of medicinal plants that found their way a long time ago into the Hindu Material Media [14].

WHO has strongly recommended for heavy metal analysis in the medicinal plants along with other necessary biological, chemical and environmental analysis [15-17]. Heavy metals are generally taken up and accumulated in plants by absorbing or adsorbing on the fruit and vegetable surfaces, either from the soil or from the polluted environments, or from the use of pesticides and fertilizers in cultivation $[18,19]$. There are many factors which play important roles in the absorbance of heavy metals by plants and these are the climatic condition, atmospheric deposition, nature of the soil and maturity of the plant species [19]. Heavy metals found in plant species are of two categories known as essential and toxic heavy metals. The essential heavy metals like $\mathrm{Cu}, \mathrm{Zn}, \mathrm{Cr}, \mathrm{Fe}, \mathrm{Mn}, \mathrm{Co}$ and $\mathrm{Ni}$ are required in very trace quantities since they are important for the physiological and biological functions of the human body and the deficiency or excess of minerals are both harmful and may lead to metabolic disorders $[20,21]$. Whereas toxic heavy metals like $\mathrm{Pb}, \mathrm{Cd}, \mathrm{As}$ and $\mathrm{Hg}$ are nonessential for human beings, animals and plants $[17,21]$. Heavy metals are not easily biodegradable and therefore they cause serious health risks in humans and animals even at very low concentration [21,22].

North-East (NE) India encompasses eight different states and these are Sikkim, Assam, Meghalaya, Arunachal Pradesh, Tripura, Mizoram, Manipur and Nagaland. The region is surrounded in the north by the Himalayas, in the east by Myanmar and in the south by the Bay of Bengal. NE India is well-known for its high ethnic and rich biological biodiversity. Assam is one among the ethnic-cultural variety and rich biodiversity states in NE India with geographical location of $\mathrm{E} 89^{\circ} 50^{\prime}$ to $\mathrm{E} 96^{\circ} 10^{\prime}$ and $\mathrm{N} 24^{\circ} 30^{\prime}$ to $\mathrm{N} 28^{\circ} 10^{\prime}$ covering the total area of 78,438 sq. $\mathrm{km}$ out of which 26,832 sq. km is covered by the forest as per the Forest Survey of India 2011 [10]. The Bodos of Assam are an important tribe and ethnic group in NE of India. They are the major and dominant inhabitant of the Bodoland Territorial Area Districts (BTAD) of Assam which mainly consists of Kokrajhar, Chirang, Baksa and Udalguri Districts. Their main food items are rice, pork, fish and other locally grown vegetables and fruits. Bodos have a huge traditional knowledge of herbal medicines and they have a rich tradition of enjoying the flavor of several wild plants in the form of mixture locally known as "Gwka-Gwkwi" (meaning bitter and sour) during the festive season of Rongjali Bwisagu, a New Year festival of Bodo people known as Rongali Bihu in Assamese. There is also a traditional belief that this Gwka-Gwkwi consumed during the festival act as a medicine for many diseases for the whole year [23]. Hence, encouraging the consumption of wild edible plants may also be 
adopted as a policy to discourse some micronutrient problems among rural populations as these are the valuable sources of energy and micronutrients. The aim of present study was to investigate the nutritional composition, phytochemical constituents, and antioxidant activities of these six wild edible plants consumed by Bodos of NE India in order to provide a good reference to the future researchers, health-conscious populaces and to provide the nutritional importance of these plants among the common people.

\section{Materials and methods}

\subsection{Chemicals}

DPPH (1, 1-diphenyl-2-picrylhydrazyl), ABTS (2, 2'-Azinobis (3-ethylbenothiazoline-6-sulfonic acid) diammonium salt) and quercetin were obtained from Himedia Laboratories Pvt. Ltd., Mumbai (India), trolox from Sigma Aldrich, Bangalore (India), $\mathrm{H}_{2} \mathrm{O}_{2}$ (Hydrogen peroxide), ascorbic acid and Folin-Ciocalteu's reagent from Merck, Mumbai (India) and gallic acid from Central Drug House Pvt. Ltd., New Delhi (India).

\subsection{Collection of plants and identification}

The six wild edible plants viz. Sphenoclea zeylanica Gaertn., Cardamine hirsuta L., Natsiatum herpeticum Buch. -Ham. ex Arn., Sphaerantus peguensis Kurtz ex C.B. Clarke, Melothria perpusilla (Blume) Cogn., and Persicaria chinensis (L) H. Gross were collected from Kokrajhar District of BTAD, Assam during their seasonal availability in the year 2014. Voucher specimens of all the plant species were submitted to Botanical Survey of India, Shillong, Meghalaya and authenticated.

\subsection{Sample preparation}

The fresh plants were washed thoroughly under tap water followed by distilled water and then moisture and vitamin $\mathrm{C}$ contents of the fresh samples were determined on the same day. The remaining samples were then dried at $55^{\circ} \mathrm{C}$ in a hot-air oven. The dried samples were powdered using a grinder. The powdered materials were extracted with methanol in 1:10 ratio (w/v), shivered, stored for $72 \mathrm{~h}$ and filtered (Whatman No. 1). Filtrate was evaporated to dryness using Buchi Rotavapor R-215 (Switzerland) and the dry extracts were kept in air-tight containers at $4^{\circ} \mathrm{C}$ in a Refrigerator till further analyses.

\subsection{Determination of proximate composition}

The Association of Official Analytical Chemists methods [24] were used for the estimation of moisture, ash, crude fat, crude protein and crude fiber. Crude fat was determined by extracting with petroleum ether using a Soxhlet apparatus. Crude protein was estimated by the Kjeldhal method. Total protein was calculated by multiplying the evaluated nitrogen by a protein conversion factor of 6.25 . Total carbohydrate was determined by the difference method [23] based on traditional carbohydrate determination. Nutritive value or the calorific value in $\mathrm{kcal} / 100 \mathrm{~g}$ of the sample was calculated [23] on the basis of data of proximate analysis. Vitamin $\mathrm{C}$ was estimated using 2, 6-dichlorophenol indophenol by titration method [23].

\subsection{Determination of metals}

Samples were digested with concentrated $\mathrm{HNO}_{3}$. Metals like $\mathrm{Ca}, \mathrm{Mg}, \mathrm{Fe}, \mathrm{Cu}, \mathrm{Zn}, \mathrm{Mn}$ and Ni were determined using Graphite Furnace-Atomic Absorption Spectrometer (GF-AAS, Analytik Jena Vario-6) at Sophisticated Analytical Instrumentation Facility (SAIF), North Eastern Hill University, Shillong (Meghalaya) and metals like 
$\mathrm{Na}, \mathrm{K}, \mathrm{Cr}, \mathrm{Co}, \mathrm{Se}, \mathrm{Pb}, \mathrm{Cd}$ and As were determined using Atomic Absorption Spectrometer (AAS-ICE 3500, Thermo Scientific, UK) at Sophisticated Analytical Instrumentation Centre (SAIC), Tezpur University (Assam). Results obtained were converted to $\mathrm{mg} / 100 \mathrm{~g}$ of dried samples.

\subsection{Phytochemical screening}

The qualitative phytochemical screening of methanol extracts of plants was performed using the reported procedures [10].

\subsection{Determination of antioxidant properties}

Using an UV-VIS spectrophotometer (Perkin Elmer, Lambda 35), antioxidant properties of methanol extracts of plants were evaluated based on previously reported procedures of DPPH, ABTS, $\mathrm{H}_{2} \mathrm{O}_{2}$, and FRAP (Ferric reducing antioxidant power) assays [3].

\subsection{Investigation of total phenolic content (TPC) and total flavonoid content (TFC)}

TPC using Folin-Ciocalteu's reagent and TFC in methanol extracts of the plant species were investigated spectrophotometrically (Perkin Elmer, Lambda 35) following the reported procedures [3]. The results of TPC and TFC were expressed in mg GAE (gallic acid equivalents)/g DE (dried extract) and mg QE (quercetin equivalents)/g DE, respectively.

\subsection{Statistical analysis}

The results of all the experiments were expressed as mean of triplicate readings \pm standard deviation. Standard deviations were calculated at Microsoft Excel. Relative significant differences among the means were determined by one-way ANOVA $t$-test at $p<0.05$ using OriginPro 8.5 software (OriginLab Corporation, MA 01060 USA). Pearson's correlation study was performed using SPSS 13.0 software.

\section{Results and discussion}

\subsection{Proximate composition}

The proximate analysis results of six wild edible plants are shown in Table 1 which shows that the moisture content of plant species varied from $82.83 \pm 1.30 \mathrm{~g}$ in M. Perpusilla to $92.89 \pm 0.44 \mathrm{~g}$ in C. hirsuta per $100 \mathrm{~g}$ of fresh sample. The moisture content of the plant species is close to the values of some underutilized green leafy vegetables reported by Saha et al. [2] and wild edible plants reported by Narzary et al. [23]. Ash content of the plants was found to be highest in $N$. herpeticum $(3.42 \pm 0.04 \mathrm{~g} / 100 \mathrm{~g})$ and lowest being in M. perpusilla $(0.661 \pm 0.008 \mathrm{~g} / 100 \mathrm{~g})$. The plant species of the present study were found to contain low amount of crude fat content that ranged from $0.124 \pm 0.11 \mathrm{~g} / 100 \mathrm{~g}$ in $S$. zeylanica to $0.666 \pm 0.01 \mathrm{~g} / 100 \mathrm{~g}$ in $N$. herpeticum which was less than $1 \%$ in all the cases and the values were found to be similar with the works of Saha et al. [2]. Table 1 showed the highest crude fiber in M. perpusilla $(3.03 \pm 0.02 \mathrm{~g} / 100 \mathrm{~g})$ and the lowest being in S. zeylanica $(1.25 \pm 0.21 \mathrm{~g} / 100 \mathrm{~g})$. Foods rich in fibers are required for digestion and effective elimination of wastes. Fibers can lower the serum cholesterol, risk of coronary heart disease, hypertension, constipation, diabetes, and colon and breast cancer [23]. The crude protein content of wild edible plant species varied from $2.64 \pm 0.13 \mathrm{~g} / 100 \mathrm{~g}$ in $M$. perpusilla to $5.37 \pm 0.05 \mathrm{~g} / 100 \mathrm{~g}$ in $N$. herpeticum. The total carbohydrate content determined was found to be ranged from $1.7 \pm 0.51 \mathrm{~g} / 100 \mathrm{~g}$ in C. hirsuta to $13.64 \pm 1.32 \mathrm{~g} / 100 \mathrm{~g}$ in M. perpusilla. The essential nutrients 
Table 1

Proximate analysis of six wild edible plants per $100 \mathrm{~g}$ of fresh weight

\begin{tabular}{lccccccc}
\hline Plants & Moisture $(\mathrm{g})$ & Ash $(\mathrm{g})$ & Fat $(\mathrm{g})$ & Fiber $(\mathrm{g})$ & Protein $(\mathrm{g})$ & Carbohydrate $(\mathrm{g})$ & Calorific value $(\mathrm{kcal})$ \\
\hline S. zeylanica & $92.81 \pm 0.64^{\mathrm{a}}$ & $1.41 \pm 0.01^{\mathrm{a}}$ & $0.124 \pm 0.11^{\mathrm{a}}$ & $1.25 \pm 0.21^{\mathrm{a}}$ & $3.08 \pm 0.01^{\mathrm{a}}$ & $2.55 \pm 0.63^{\mathrm{a}}$ & $23.70 \pm 2.54^{\mathrm{a}}$ \\
C. hirsuta & $92.89 \pm 0.44^{\mathrm{a}}$ & $1.78 \pm 0.07^{\mathrm{a}}$ & $0.239 \pm 0.01^{\mathrm{a}}$ & $1.64 \pm 0.01^{\mathrm{a}} \mathrm{b}$ & $3.99 \pm 0.21^{\mathrm{b}}$ & $1.70 \pm 0.51^{\mathrm{b}}$ & $22.45 \pm 2.06^{\mathrm{b}}$ \\
N. herpeticum & $83.72 \pm 2.36^{\mathrm{b}}$ & $3.42 \pm 0.04^{\mathrm{b}}$ & $0.666 \pm 0.01^{\mathrm{a}}$ & $1.99 \pm 0.03^{\mathrm{b}}$ & $5.37 \pm 0.05^{\mathrm{c}}$ & $6.80 \pm 2.40^{\mathrm{c}}$ & $54.72 \pm 9.61^{\mathrm{c}}$ \\
S. peguensis & $90.89 \pm 2.22^{\mathrm{c}}$ & $2.35 \pm 0.12^{\mathrm{c}}$ & $0.254 \pm 0.03^{\mathrm{a}}$ & $1.92 \pm 0.07^{\mathrm{b}}$ & $3.18 \pm 0.01^{\mathrm{a}}$ & $3.32 \pm 2.23^{\mathrm{d}}$ & $28.30 \pm 8.91^{\mathrm{d}}$ \\
M. perpusilla & $82.83 \pm 1.30^{\mathrm{d}}$ & $0.661 \pm 0.01^{\mathrm{d}}$ & $0.208 \pm 0.22^{\mathrm{a}}$ & $3.03 \pm 0.02^{\mathrm{c}}$ & $2.64 \pm 0.13^{\mathrm{d}}$ & $13.64 \pm 1.32^{\mathrm{e}}$ & $67.03 \pm 5.23^{\mathrm{e}}$ \\
P. chinensis & $92.35 \pm 0.61^{\mathrm{a}}$ & $1.58 \pm 0.11^{\mathrm{a}}$ & $0.333 \pm 0.02^{\mathrm{a}}$ & $2.57 \pm 0.52^{\mathrm{d}}$ & $3.66 \pm 0.22^{\mathrm{b}}$ & $2.07 \pm 0.61^{\mathrm{a}}$ & $25.93 \pm 2.43^{\mathrm{f}}$ \\
\hline
\end{tabular}

Results are expressed as mean of triplicate readings $(n=3) \pm$ standard deviation per $100 \mathrm{~g}$ of fresh sample. The results with different letters in a column are significantly different from each other at $p<0.05$.

of life are carbohydrates, fats and proteins. High carbohydrate content indicates high energy content in food. The main function of carbohydrate in the body is to supply energy and it is responsible for doing activities in our daily life [10,23]. The calorific value per $100 \mathrm{~g}$ of fresh sample was found highest in M. perpusilla $(67.03 \pm 5.229 \mathrm{kcal})$ followed by $N$. herpeticum $(54.72 \pm 9.61 \mathrm{kcal})$ and lowest in $C$. hirsuta $(22.45 \pm 2.06 \mathrm{kcal})$. Similarly, Narzary et al. [23] studied the calorific value of some wild edible plants and reported to range from 29.48 to $67.42 \mathrm{kcal}$ per $100 \mathrm{~g}$ of fresh sample which is close to the values of present study. Foods with a high calorific value can be considered as a good human diet. These wild edible plants with high calorific value can be suggested in the formulation of numerous nutritional supplements.

\subsection{Metal contents}

Metal contents of six wild edible plants expressed in $\mathrm{mg} / 100 \mathrm{~g}$ dried sample are shown in Table 2 . The sodium and potassium detected in the plants ranged from $48.73 \pm 0.13 \mathrm{mg}$ to $136.71 \pm 0.20 \mathrm{mg}$ and $1155.28 \pm 0.21 \mathrm{mg}$ to $10462.28 \pm 0.13 \mathrm{mg}$, respectively. The plants are very rich in potassium and the increasing order of potassium content is $P$. chinensis $<M$. perpusilla $<S$. zeylanica $<N$. herpeticum $<S$. peguensis $<C$. hirsuta. Potassium is one of the most important nutrients which plays various biophysical and biochemical roles and plant foods rich in potassium are generally used for the treatment of rheumatoid arthritis and heart disease [12, 21]. In this investigation, low levels of calcium $(5.00 \pm 0.01-6.22 \pm 0.03 \mathrm{mg} / 100 \mathrm{~g})$ and magnesium $(4.10 \pm 0.02-$ $5.60 \pm 0.02 \mathrm{mg} / 100 \mathrm{~g}$ ) were found to be present. Magnesium is important in the ionic balance and enzyme co-factors, and calcium is required in building of skeletal structures and muscle functioning [25]. Magnesium cooperates with calcium in the muscular contraction and blood coagulation [20]. Iron content was detected highest in $C$. hirsuta $(6.10 \pm 0.01 \mathrm{mg} / 100 \mathrm{~g})$ and lowest value in $P$. chinensis $(1.60 \pm 0.16 \mathrm{mg} / 100 \mathrm{~g})$. The iron content of lesser known leafy vegetables reported by Bello et al. [26] was comparable to the report of present investigation. Saha et al. [2] reported the iron content of some underutilized green leafy vegetables of Sonitpur district of Assam, India ranging from $29.40 \mathrm{mg} / 100 \mathrm{~g}$ to $241.20 \mathrm{mg} / 100 \mathrm{~g}$ which is higher in comparison to values of present study. $\mathrm{Ng}$ et al. [27] also reported the iron content of selected tropical wild vegetables which ranged from $3.6-33.1 \mathrm{mg} / 100 \mathrm{~g}$. The recommended daily intake of iron for adult female is $29 \mathrm{mg}$ per day and for adult male is $8 \mathrm{mg}$ per day. Iron is needed for normal functioning of the central nervous system and for the synthesis of haemoglobin in red blood cells which is required for oxygen transportation to all parts of the body. Iron deficiency is linked to anaemia and causes immune system dysfunction which is associated with increased risk of infection $[1,10,27]$. When dietary iron consumption is not sufficient, about $15 \%$ of the body's iron stored for future supplies is mobilized [28]. The level of copper ranged from $1.62 \pm 0.03 \mathrm{mg}$ in $C$. hirsuta (lowest) to $2.60 \pm 0.41 \mathrm{mg}$ in $P$. chinensis (highest) per $100 \mathrm{~g}$ of dried sample. Almost similar value of copper was detected in $S$. zeylanica, $M$. perpusilla and $P$. chinensis. Copper plays an important role in biological electron transport and is essential for the production of enzyme in the body [2]. Deficiency of copper leads to reduced energy 
Table 2

Metal analysis of six wild edible plants ( $\mathrm{mg} / 100 \mathrm{~g}$ dried sample)

\begin{tabular}{lrrrrrr}
\hline Metals & \multicolumn{5}{c}{ Plant species } \\
\cline { 2 - 7 } & S. zeylanica & C. hirsuta & N. herpeticum & S. peguensis & M. perpusilla & P. chinensis \\
\hline $\mathrm{Na}$ & $48.73 \pm 0.13^{\mathrm{a}}$ & $100.48 \pm 0.20^{\mathrm{b}}$ & $92.15 \pm 0.02^{\mathrm{c}}$ & $136.71 \pm 0.20^{\mathrm{d}}$ & $55.35 \pm 0.30^{\mathrm{e}}$ & $53.35 \pm 0.06^{\mathrm{f}}$ \\
$\mathrm{K}$ & $7684.29 \pm 0.15^{\mathrm{a}}$ & $10462.28 \pm 0.13^{\mathrm{b}}$ & $8436.10 \pm 0.09^{\mathrm{c}}$ & $10164.25 \pm 0.10^{\mathrm{d}}$ & $5886.17 \pm 0.16^{\mathrm{e}}$ & $1155.28 \pm 0.21^{\mathrm{f}}$ \\
$\mathrm{Ca}$ & $6.22 \pm 0.03^{\mathrm{a}}$ & $6.20 \pm 0.14^{\mathrm{a}}$ & $5.47 \pm 0.02^{\mathrm{b}}$ & $5.00 \pm 0.01^{\mathrm{b}}$ & $6.14 \pm 0.04^{\mathrm{a}}$ & $5.11 \pm 0.02^{\mathrm{b}}$ \\
$\mathrm{Mg}$ & $4.90 \pm 0.01^{\mathrm{a}}$ & $5.60 \pm 0.02^{\mathrm{b}}$ & $4.58 \pm 0.03^{\mathrm{a}, \mathrm{c}}$ & $4.10 \pm 0.02^{\mathrm{c}}$ & $5.10 \pm 0.01^{\mathrm{b}}$ & $4.20 \pm 0.06^{\mathrm{c}}$ \\
$\mathrm{Fe}$ & $1.83 \pm 0.05^{\mathrm{a}}$ & $6.10 \pm 0.01^{\mathrm{b}}$ & $2.48 \pm 0.01^{\mathrm{c}}$ & $2.40 \pm 0.06^{\mathrm{c}}$ & $1.70 \pm 0.07^{\mathrm{a}}$ & $1.60 \pm 0.16^{\mathrm{a}}$ \\
$\mathrm{Cu}$ & $2.58 \pm 0.07^{\mathrm{a}}$ & $1.62 \pm 0.03^{\mathrm{b}}$ & $2.10 \pm 0.01^{\mathrm{a}}$ & $2.11 \pm 0.02^{\mathrm{a}}$ & $2.60 \pm 0.01^{\mathrm{a}, \mathrm{c}}$ & $2.60 \pm 0.41^{\mathrm{a}, \mathrm{c}}$ \\
$\mathrm{Zn}$ & $0.70 \pm 0.05^{\mathrm{a}}$ & $0.30 \pm 0.01^{\mathrm{a}}$ & $0.70 \pm 0.02^{\mathrm{a}}$ & $0.20 \pm 0.01^{\mathrm{a}}$ & $0.20 \pm 0.03^{\mathrm{a}}$ & $0.30 \pm 0.05^{\mathrm{a}}$ \\
$\mathrm{Mn}$ & $0.54 \pm 0.04^{\mathrm{a}}$ & $0.64 \pm 0.03^{\mathrm{a}}$ & $0.70 \pm 0.01^{\mathrm{a}}$ & $0.62 \pm 0.03^{\mathrm{a}}$ & $0.80 \pm 0.14^{\mathrm{a}}$ & $0.60 \pm 0.02^{\mathrm{a}}$ \\
$\mathrm{Ni}$ & $2.60 \pm 0.02^{\mathrm{a}}$ & $3.60 \pm 0.03^{\mathrm{b}}$ & $4.70 \pm 0.06^{\mathrm{c}}$ & $4.20 \pm 0.02^{\mathrm{c}}$ & $3.80 \pm 0.02^{\mathrm{b}}$ & $4.70 \pm 0.08^{\mathrm{d}}$ \\
$\mathrm{Cr}$ & $0.58 \pm 0.03^{\mathrm{a}}$ & $0.87 \pm 0.02^{\mathrm{a}}$ & $0.74 \pm 0.09^{\mathrm{a}}$ & $2.36 \pm 0.01^{\mathrm{b}}$ & $1.32 \pm 0.12^{\mathrm{c}}$ & $2.38 \pm 0.19^{\mathrm{b}}$ \\
$\mathrm{Co}$ & $0.39 \pm 0.11^{\mathrm{a}}$ & $0.57 \pm 0.02^{\mathrm{a}}$ & $0.59 \pm 0.12^{\mathrm{a}}$ & $0.57 \pm 0.16^{\mathrm{a}}$ & $0.26 \pm 0.09^{\mathrm{a}}$ & $0.36 \pm 0.07^{\mathrm{a}}$ \\
$\mathrm{Se}$ & $0.81 \pm 0.40^{\mathrm{a}}$ & $1.83 \pm 0.60^{\mathrm{b}}$ & $0.78 \pm 0.41^{\mathrm{a}}$ & $0.45 \pm 0.90^{\mathrm{a}}$ & $0.37 \pm 0.53^{\mathrm{a}}$ & $0.84 \pm 0.24^{\mathrm{a}}$ \\
$\mathrm{Pb}$ & $0.59 \pm 0.11^{\mathrm{a}}$ & $0.86 \pm 0.31^{\mathrm{a}}$ & $0.75 \pm 0.51^{\mathrm{a}}$ & $2.36 \pm 0.21^{\mathrm{b}}$ & $1.32 \pm 0.16^{\mathrm{c}}$ & $2.39 \pm 0.31^{\mathrm{b}}$ \\
$\mathrm{Cd}$ & & & & & & \\
$\mathrm{As}$ & & & & & &
\end{tabular}

BDL, Below detection level; Results are expressed as mean of triplicate readings $(n=3) \pm$ standard deviation per $100 \mathrm{~g}$ of dried sample. The results with different letters along a row are significantly different from each other at $p<0.05$.

production, abnormal glucose and cholesterol metabolism, and increased oxidative damage [10, 29]. The zinc content of the plant species varied from $0.20 \pm 0.01 \mathrm{mg}$ to $0.70 \pm 0.05 \mathrm{mg}$ with the highest being in $S$. zeylanica and the lowest value in $S$. peguensis. However, a higher level of zinc was reported in some underutilized green leafy vegetables by Saha et al. [2] that ranged from $1.50 \mathrm{mg} / 100 \mathrm{~g}$ to $7.50 \mathrm{mg} / 100 \mathrm{~g}$. The recommended dietary allowance for zinc is $8 \mathrm{mg}$ and $11 \mathrm{mg}$ per day for adult women and men respectively [30]. Zinc is an essential element for human growth which increases resistance to infection and excessive intake of zinc has been reported to be toxic [10, 31]. Zinc is a cofactor for the antioxidant enzyme super oxide dismutase. It is required for the functioning of over 300 different enzymes, and many enzymatic reactions involved in carbohydrate and protein metabolism [28]. The manganese content found in the present study (Table 2) varied from $0.54 \pm 0.04 \mathrm{mg}$ in S. zeylanica to $0.80 \pm 0.14 \mathrm{mg}$ in M. perpusilla. Manganese is an important component of metalloenzymes and plays essential roles in a number of physiological processes as a constituent or activator of some enzymes which are essential for the metabolism of carbohydrate, cholesterol and amino acid [29]. The highest nickel content was detected in P. chinensis $(4.70 \pm 0.06 \mathrm{mg})$ and lowest in $S$. zeylanica $(2.60 \pm 0.02 \mathrm{mg})$. Chromium, cobalt and selenium content varied from $0.58 \pm 0.03 \mathrm{mg}$ (S. zeylanica) to $2.38 \pm 0.19 \mathrm{mg}$ (P. chinensis), $0.26 \pm 0.09 \mathrm{mg}(M$. perpusilla) to $0.59 \pm 0.12 \mathrm{mg}$ ( N. herpeticum) and $0.37 \pm 0.53 \mathrm{mg}$ (M. perpusilla) to $1.83 \pm 0.60 \mathrm{mg}$ (C. hirsuta), respectively. $S$. zeylanica $(0.59 \pm 0.11 \mathrm{mg})$ had the lowest lead content and the highest level was detected in P. chinensis $(2.39 \pm 0.31 \mathrm{mg})$. Cadmium and arsenic were not detected (below detection level) in the plants.

\subsection{Phytochemical screening}

The preliminary screening of phytochemical constituents present in six wild edible plants was performed using methanol extract. The phytochemical constituents investigated were alkaloids, saponins, cardiac glycosides, steroids, anthraquinones, coumarins, phenols, tannins, flavonoids, anthocyanins, phlobatannins, carbohydrates, starch, proteins, and lignin. The results were summarized in Table 3 which showed the presence of various 
Table 3

Qualitative phytochemical analysis with methanol extracts of plants

\begin{tabular}{|c|c|c|c|c|c|c|c|}
\hline Phytochemicals & Name of Test & $\mathrm{SZ}$ & $\mathrm{CH}$ & $\mathrm{NH}$ & SP & MP & $\mathrm{PC}$ \\
\hline \multirow[t]{2}{*}{ Alkaloids } & Wagner's reagent & + & + & + & + & + & + \\
\hline & Dragendroff's reagent & + & + & + & + & + & + \\
\hline Saponins & Frothing test & + & + & + & + & + & + \\
\hline Cardiac glycosides & Keller-Killiani’s test & + & + & + & + & + & + \\
\hline \multirow[t]{2}{*}{ Steroids } & Liebermann-Burchard test & + & + & + & + & + & + \\
\hline & Salkowski's test & + & + & + & + & + & + \\
\hline Anthraquinones & Modified Borntrager's test & - & + & - & + & + & + \\
\hline Coumarins & & + & + & + & + & + & + \\
\hline Phenols & $\mathrm{FeCl}_{3}$ test & - & - & + & + & + & + \\
\hline Tannins & Gelatine test & - & + & + & + & + & + \\
\hline Flavonoids & Shinoda's test & + & + & + & + & + & + \\
\hline Anthocyanin & & - & - & + & - & + & + \\
\hline Phlobatannins & & - & - & + & - & - & + \\
\hline \multirow[t]{2}{*}{ Carbohydrates } & Molish's test & + & + & + & + & + & + \\
\hline & Felhing's test & - & + & + & + & + & + \\
\hline Starch & Iodine test & - & - & - & - & - & + \\
\hline \multirow[t]{2}{*}{ Proteins } & Ninhydrin test & - & - & + & - & - & + \\
\hline & Millon's test & + & + & + & + & + & + \\
\hline Lignin & & - & + & + & + & + & + \\
\hline
\end{tabular}

Sphenoclea zeylanica (SZ), Cardamine hirsuta (CH), Natsiatum herpeticum (NH), Sphaerantus peguensis (SP), Melothria perpusilla (MP), Persicaria chinensis (PC); (+), present; (-), absent.

bioactive compounds. Fruits and vegetables are very important sources of bioactive compounds that differ widely in terms of structure, biological properties, and mechanisms of actions. Many phytochemical constituents found in plants are known to be responsible for antioxidant, antimicrobial, anti-larvicidal, and anti-inflammatory activities $[10,25]$.

\subsection{Antioxidant property}

DPPH free radical scavenging activity of methanolic extract of six wild plants is shown in Table 4 . The DPPH method is widely used for screening antioxidant activity of plant extracts. DPPH is a stable free radical having a characteristic absorption at $517 \mathrm{~nm}$. Antioxidants in the extracts react with DPPH and convert 1, 1-diphenyl-2picrylhydrazyl (deep violet color) to 1, 1-diphenyl-2-picrylhydrazine, a stable molecule (yellow color or bleached product) by accepting an electron or hydrogen radical at a very rapid rate resulting in a decrease in absorbance at $517 \mathrm{~nm}$ [10]. $\mathrm{IC}_{50}$ value is defined as the inhibitory concentration of the crude extract that scavenges $50 \%$ of reactive oxygen species or inhibits the process of oxidation by 50\%. It is inversely related to antioxidant capacity and lower $\mathrm{IC}_{50}$ value signals better antioxidant activity. In this investigation, all the plant extracts were compared with ascorbic acid as standard reference. The methanol extract of all the wild edible plants showed DPPH free radical scavenging activity and the antioxidant activity increases with increasing concentration of sample extract (Table 4). The results showed that $M$. perpusilla $(97.54 \pm 0.15 \%)$ had the highest DPPH radical scavenging activity with an $\mathrm{IC}_{50}$ value of $134.96 \pm 0.35 \mu \mathrm{g} / \mathrm{mL}$ and $N$. herpeticum $(24.85 \pm 0.07 \%)$ had the lowest activity with $\mathrm{IC}_{50}$ value of $1658.47 \pm 2.72 \mu \mathrm{g} / \mathrm{mL}$. While the standard ascorbic acid showed $98.84 \pm 0.10 \%$ inhibition with an $\mathrm{IC}_{50}$ value of $25.01 \pm 0.52 \mu \mathrm{g} / \mathrm{mL}$. 
Table 4

DPPH, ABTS and $\mathrm{H}_{2} \mathrm{O}_{2}$ scavenging activities of methanolic extracts of plants

\begin{tabular}{|c|c|c|c|c|c|c|c|}
\hline $\begin{array}{l}\text { Conc. } \\
(\mu \mathrm{g} / \mathrm{mL})\end{array}$ & S. zeylanica & C. hirsuta & N. herpeticum & S. peguensis & M. perpusilla & P. chinensis & Standard** \\
\hline \multicolumn{8}{|c|}{ Inhibition (\%) of plants for DPPH assay } \\
\hline 2 & $12.60 \pm 0.28^{\mathrm{a}}$ & $12.73 \pm 0.09^{\mathrm{a}}$ & $14.48 \pm 0.07^{\mathrm{b}}$ & $17.18 \pm 0.07^{\mathrm{c}}$ & $14.59 \pm 0.12^{\mathrm{b}}$ & $8.75 \pm 0.09^{\mathrm{d}}$ & $15.94 \pm 0.14^{\mathrm{e}}$ \\
\hline 5 & $13.82 \pm 0.05^{\mathrm{a}}$ & $13.20 \pm 0.09^{\mathrm{b}}$ & $15.14 \pm 0.07^{\mathrm{c}}$ & $18.28 \pm 0.34^{\mathrm{d}}$ & $19.71 \pm 0.23^{\mathrm{e}}$ & $14.65 \pm 0.13^{\mathrm{f}}$ & $26.93 \pm 0.19^{\mathrm{g}}$ \\
\hline 10 & $14.91 \pm 0.14^{\mathrm{a}}$ & $14.04 \pm 0.09^{\mathrm{b}}$ & $16.15 \pm 0.04^{\mathrm{c}}$ & $19.47 \pm 0.41^{\mathrm{d}}$ & $25.17 \pm 0.15^{\mathrm{e}}$ & $16.33 \pm 0.09^{\mathrm{f}}$ & $36.57 \pm 0.28^{\mathrm{g}}$ \\
\hline 50 & $17.19 \pm 0.35^{\mathrm{a}}$ & $15.63 \pm 0.09^{\mathrm{b}}$ & $17.18 \pm 0.11^{\mathrm{a}}$ & $22.61 \pm 0.12^{\mathrm{c}}$ & $41.09 \pm 0.28^{\mathrm{d}}$ & $17.62 \pm 0.27^{\mathrm{a}}$ & $83.11 \pm 0.23^{\mathrm{e}}$ \\
\hline 100 & $20.31 \pm 0.09^{\mathrm{a}}$ & $16.63 \pm 0.10^{\mathrm{b}}$ & $18.67 \pm 0.51^{\mathrm{c}}$ & $24.54 \pm 0.15^{\mathrm{d}}$ & $47.92 \pm 0.19^{\mathrm{e}}$ & $21.14 \pm 0.22^{\mathrm{f}}$ & $90.04 \pm 0.23^{\mathrm{g}}$ \\
\hline 200 & $34.61 \pm 0.42^{\mathrm{a}}$ & $22.00 \pm 0.18^{\mathrm{b}}$ & $23.28 \pm 0.22^{\mathrm{c}}$ & $36.81 \pm 0.15^{\mathrm{d}}$ & $91.00 \pm 0.27^{\mathrm{e}}$ & $30.08 \pm 0.31^{\mathrm{f}}$ & $93.03 \pm 0.47^{\mathrm{g}}$ \\
\hline 500 & $46.25 \pm 0.33^{\mathrm{a}}$ & $31.42 \pm 0.19^{\mathrm{b}}$ & $24.85 \pm 0.07^{\mathrm{c}}$ & $51.43 \pm 0.16^{\mathrm{d}}$ & $97.54 \pm 0.15^{\mathrm{e}}$ & $45.21 \pm 0.27^{f}$ & $98.84 \pm 0.10^{\mathrm{g}}$ \\
\hline $\mathrm{IC}_{50}$ & $519.90 \pm 2.88^{\mathrm{a}}$ & $989.98 \pm 6.07^{b}$ & $1658.47 \pm 2.72^{\mathrm{c}}$ & $455.76 \pm 0.87^{\mathrm{d}}$ & $134.96 \pm 0.35^{\mathrm{e}}$ & $550.68 \pm 2.86^{\mathrm{f}}$ & $25.01 \pm 0.52^{g}$ \\
\hline \multicolumn{8}{|c|}{ Inhibition (\%) of plants for ABTS assay } \\
\hline 20 & $15.46 \pm 0.14^{\mathrm{a}}$ & $2.33 \pm 0.09^{b}$ & $8.74 \pm 0.14^{\mathrm{c}}$ & $16.24 \pm 0.24^{\mathrm{d}}$ & $10.81 \pm 2.01^{\mathrm{e}}$ & $14.81 \pm 0.23^{\mathrm{f}}$ & $11.41 \pm 0.22^{\mathrm{g}}$ \\
\hline 50 & $31.40 \pm 0.08^{\mathrm{a}}$ & $3.60 \pm 0.18^{\mathrm{b}}$ & $16.19 \pm 0.22^{\mathrm{c}}$ & $16.74 \pm 0.23^{\mathrm{c}}$ & $18.24 \pm 0.22^{\mathrm{d}}$ & $16.64 \pm 0.23^{\mathrm{c}}$ & $47.98 \pm 0.14^{\mathrm{e}}$ \\
\hline 100 & $47.44 \pm 0.08^{\mathrm{a}}$ & $6.62 \pm 0.23^{\mathrm{b}}$ & $20.00 \pm 0.14^{\mathrm{c}}$ & $24.37 \pm 0.24^{\mathrm{d}}$ & $23.82 \pm 0.16^{\mathrm{e}}$ & $26.38 \pm 0.08^{\mathrm{f}}$ & $69.10 \pm 0.22^{\mathrm{g}}$ \\
\hline 150 & $67.63 \pm 0.14^{\mathrm{a}}$ & $7.36 \pm 0.24^{\mathrm{b}}$ & $28.34 \pm 0.08^{c}$ & $34.48 \pm 0.23^{\mathrm{d}}$ & $41.58 \pm 0.22^{\mathrm{e}}$ & $33.07 \pm 0.24^{\mathrm{f}}$ & $87.89 \pm 0.29^{\mathrm{g}}$ \\
\hline 200 & $79.91 \pm 0.14^{\mathrm{a}}$ & $8.42 \pm 0.15^{\mathrm{b}}$ & $35.01 \pm 0.22^{\mathrm{c}}$ & $49.58 \pm 0.23^{\mathrm{d}}$ & $58.95 \pm 0.14^{\mathrm{e}}$ & $44.44 \pm 0.15^{\mathrm{f}}$ & $92.17 \pm 0.17^{\mathrm{g}}$ \\
\hline 250 & $87.86 \pm 0.14^{\mathrm{a}}$ & $15.73 \pm 0.15^{\mathrm{b}}$ & $44.98 \pm 0.23^{\mathrm{c}}$ & $60.84 \pm 0.15^{\mathrm{d}}$ & $80.54 \pm 0.22^{\mathrm{e}}$ & $50.43 \pm 0.23^{\mathrm{f}}$ & $94.76 \pm 0.14^{\mathrm{g}}$ \\
\hline 300 & $91.71 \pm 0.08^{\mathrm{a}}$ & $23.74 \pm 0.18^{\mathrm{b}}$ & $54.27 \pm 0.22^{\mathrm{c}}$ & $63.99 \pm 0.16^{\mathrm{d}}$ & $90.29 \pm 0.23^{\mathrm{e}}$ & $59.25 \pm 0.23^{\mathrm{f}}$ & $96.46 \pm 0.22^{\mathrm{g}}$ \\
\hline $\mathrm{IC}_{50}$ & $115.99 \pm 0.12^{\mathrm{a}}$ & $746.46 \pm 1.90^{\mathrm{b}}$ & $283.23 \pm 0.49^{\mathrm{c}}$ & $214.86 \pm 0.65^{\mathrm{d}}$ & $165.18 \pm 0.25^{\mathrm{e}}$ & $244.36 \pm 0.50^{\mathrm{f}}$ & $73.67 \pm 0.74^{\mathrm{g}}$ \\
\hline \multicolumn{8}{|c|}{ Inhibition (\%) of plants for $\mathrm{H}_{2} \mathrm{O}_{2}$ assay } \\
\hline 5 & $0.76 \pm 0.03^{\mathrm{a}}$ & $2.27 \pm 0.06^{\mathrm{b}}$ & $7.71 \pm 0.07^{\mathrm{c}}$ & $3.99 \pm 0.09^{\mathrm{d}}$ & $9.63 \pm 0.13^{\mathrm{e}}$ & $3.40 \pm 0.07^{\mathrm{f}}$ & $10.73 \pm 0.02^{\mathrm{g}}$ \\
\hline 10 & $1.33 \pm 0.04^{\mathrm{a}}$ & $2.89 \pm 0.03^{b}$ & $9.80 \pm 0.91^{\mathrm{c}}$ & $6.81 \pm 0.07^{\mathrm{d}}$ & $15.23 \pm 0.11^{\mathrm{e}}$ & $5.82 \pm 0.07^{\mathrm{f}}$ & $27.91 \pm 0.04^{\mathrm{g}}$ \\
\hline 15 & $3.95 \pm 0.03^{\mathrm{a}}$ & $4.74 \pm 0.06^{\mathrm{b}}$ & $16.02 \pm 0.07^{\mathrm{c}}$ & $7.46 \pm 0.07^{\mathrm{d}}$ & $23.51 \pm 0.06^{\mathrm{e}}$ & $14.96 \pm 0.09^{\mathrm{f}}$ & $41.96 \pm 0.07^{\mathrm{g}}$ \\
\hline 20 & $6.95 \pm 0.03^{\mathrm{a}}$ & $10.39 \pm 0.03^{b}$ & $18.77 \pm 0.07^{\mathrm{c}}$ & $16.46 \pm 0.08^{\mathrm{d}}$ & $25.7 \pm 0.14^{\mathrm{e}}$ & $22.56 \pm 0.05^{\mathrm{f}}$ & $51.42 \pm 0.07^{\mathrm{g}}$ \\
\hline 25 & $8.51 \pm 0.04^{\mathrm{a}}$ & $14.49 \pm 0.06^{\mathrm{b}}$ & $37.12 \pm 0.02^{\mathrm{c}}$ & $21.91 \pm 0.07^{\mathrm{d}}$ & $28.75 \pm 0.13^{\mathrm{e}}$ & $27.29 \pm 0.07^{\mathrm{f}}$ & $64.86 \pm 0.08^{\mathrm{g}}$ \\
\hline $\mathrm{IC}_{50}$ & $123.19 \pm 0.54^{\mathrm{a}}$ & $82.34 \pm 0.53^{\mathrm{b}}$ & $38.54 \pm 0.19^{c}$ & $57.49 \pm 0.26^{\mathrm{d}}$ & $45.2 \pm 0.09^{\mathrm{e}}$ & $42.26 \pm 0.04^{\mathrm{f}}$ & $19.02 \pm 0.01^{\mathrm{g}}$ \\
\hline
\end{tabular}

Conc., concentration; $\mathrm{IC}_{50}$ value in $\mu \mathrm{g} / \mathrm{mL}$; Standard**, Standard used was ascorbic acid for both DPPH and $\mathrm{H}_{2} \mathrm{O}_{2}$ assays and trolox for ABTS assay; Results are expressed as mean of 3 replicates \pm standard deviation. The results with different letters along a row are significantly different from each other at $p<0.05$.

ABTS radical scavenging activity of methanolic extract of six wild plants is shown in Table 4. The ABTS radical scavenging activity was found highest in methanol extract of $S$. zeylanica $(91.71 \pm 0.08 \%)$ followed by $M$. perpusilla $(90.29 \pm 0.23 \%)$ with an $\mathrm{IC}_{50}$ value of $115.99 \pm 0.12 \mu \mathrm{g} / \mathrm{mL}$ and $165.18 \pm 0.25 \mu \mathrm{g} / \mathrm{mL}$ respectively, whereas $C$. hirsuta $(23.74 \pm 0.18 \%)$ exhibited the lowest activity among the selected plants with $\mathrm{IC}_{50}$ value of $746.46 \pm 1.9 \mu \mathrm{g} / \mathrm{mL}$. Trolox was used as standard in ABTS assay and displayed an $\mathrm{IC}_{50}$ value $73.67 \pm 0.74 \mu \mathrm{g} / \mathrm{mL}$ (Table 4). ABTS $\mathrm{IC}_{50}$ value is the effective concentration of methanol extract in $\mu \mathrm{g} / \mathrm{mL}$ which inhibits the ABTS activity by $50 \%$. ABTS $^{+}$radical is stable free radical and accepts an electron or hydrogen radical from antioxidant compounds to become a stable molecule which inhibits initiation or propagation of free-radical chain of oxidation. This study showed that the extracts of $S$. zeylanica and M. perpusilla were potent antioxidants. It has been reported that the high molecular weight phenolics (tannins) have more ability to quench free radicals $\left(\mathrm{ABTS}^{+}\right)$and their effectiveness depends on the molecular weight, number of aromatic rings, and nature of hydroxyl group's substitution than the specific functional groups [25]. 
Table 5

Ferric reducing antioxidant power (FRAP) and phytochemical contents of six wild edible plants

\begin{tabular}{lcccr}
\hline Plants & $\begin{array}{c}\text { FRAP } \\
(\mu \mathrm{M} \mathrm{TE} / \mathrm{g} \mathrm{DE})\end{array}$ & $\begin{array}{c}\text { Phenolic } \\
(\mathrm{mg} \mathrm{GAE} / \mathrm{g} \mathrm{DE})\end{array}$ & $\begin{array}{c}\text { Flavonoid } \\
(\mathrm{mg} \mathrm{QE} / \mathrm{g} \mathrm{DE})\end{array}$ & $\begin{array}{c}\text { Vitamin C } \\
(\mathrm{mg} / 100 \mathrm{~g} \mathrm{FW})\end{array}$ \\
\hline S. zeylanica & $38.57 \pm 7.14^{\mathrm{a}}$ & $36.39 \pm 5.31^{\mathrm{a}}$ & $0.23 \pm 0.10^{\mathrm{a}}$ & $40.37 \pm 1.63^{\mathrm{a}}$ \\
C. hirsuta $_{\text {N. } \text { herpeticum }}$ & $50.47 \pm 5.45^{\mathrm{b}}$ & $71.77 \pm 5.81^{\mathrm{b}}$ & $0.47 \pm 0.23^{\mathrm{a}}$ & $35.62 \pm 3.25^{\mathrm{b}}$ \\
S. peguensis & $60.01 \pm 3.57^{\mathrm{c}}$ & $10.45 \pm 0.68^{\mathrm{c}}$ & $0.29 \pm 0.11^{\mathrm{a}}$ & $85.71 \pm 5.71^{\mathrm{c}}$ \\
M. perpusilla & $115.95 \pm 5.45^{\mathrm{d}}$ & $54.08 \pm 7.21^{\mathrm{d}}$ & $0.77 \pm 0.19^{\mathrm{a}}$ & $15.24 \pm 1.65^{\mathrm{d}}$ \\
P. chinensis & $855.23 \pm 10.91^{\mathrm{e}}$ & $239.62 \pm 5.4^{\mathrm{e}}$ & $1.66 \pm 0.10^{\mathrm{b}}$ & $57.07 \pm 1.59^{\mathrm{e}}$ \\
\hline
\end{tabular}

DE, Dried extract; FW, Fresh weight; Results are expressed as mean of 3 replicates \pm standard deviation. The results with different letters in a column are significantly different from each other at $p<0.05$.

$\mathrm{H}_{2} \mathrm{O}_{2}$ scavenging activity of methanolic extract of six wild plants is shown in Table 4 and compared with the standard ascorbic acid. The percentage of scavenging activity was found highest in $N$. herpeticum extract with an $\mathrm{IC}_{50}$ value of $38.54 \pm 0.19 \mu \mathrm{g} / \mathrm{mL}$, while standard ascorbic acid exhibited an $\mathrm{IC}_{50}$ value of $19.02 \pm 0.01 \mu \mathrm{g} / \mathrm{mL}$. $S$. zeylanica plant extract exhibited lowest $\mathrm{H}_{2} \mathrm{O}_{2}$ scavenging activity showing an $\mathrm{IC}_{50}$ value of $123.19 \pm 0.54 \mu \mathrm{g} / \mathrm{mL}$. Hydrogen peroxide, a non-radical reactive oxygen species in living organisms, itself is not very reactive but sometimes it is toxic to cells because it has the ability to penetrate cell membranes which may give rise to hydroxyl radicals and singlet oxygen, and initiate oxidation in the cells [32]. Therefore, removing $\mathrm{of}_{2} \mathrm{H}_{2}$ by natural antioxidant sources is very important for protection of biological systems. Food polyphenols have been shown to defend mammalian and bacterial cells from cytotoxicity induced by hydrogen peroxide, especially compounds with the orthodihydroxy phenolic structure, quercetin, catechin, gallic acid ester, and caffeic acid ester [25].

Ferric reducing antioxidant power (FRAP) assay was another method used to investigate the antioxidant activity of the wild plants in this study. The FRAP assay is a simple, inexpensive and widely employed method for the assessment of antioxidant activity and is based on the capacity of antioxidants to reduce ferric (III) ions to ferrous (II) ions [33]. Higher FRAP value indicates higher antioxidant activity. In this study, FRAP values (Table 5) ranged from $38.57 \pm 7.14$ to $855.23 \pm 10.91 \mu \mathrm{M}$ TE/g DE showing the strongest antioxidant activity in $M$. perpusilla extract while $S$. zeylanica had the lowest activity. The high activity may be due to the antioxidant compounds present in the methanol extracts of plants which could react with free radicals to stabilize and prevent radical chain reactions. Free radical scavenging is a very important function of antioxidants as free radicals encourage oxidation of proteins, DNA, and lipids which results in disturbances and functional loss of biological membranes and enzymes, and ultimately produces toxins [34].

\subsection{Phenolic, flavonoid and vitamin C contents}

Phenolic, flavonoid and vitamin $\mathrm{C}$ contents of six wild edible plants are presented in Table 5. The total phenolic content in the methanol extract of plants ranged from $10.45 \pm 0.68$ to $239.62 \pm 5.4 \mathrm{mg} \mathrm{GAE} / \mathrm{g} \mathrm{DE}$. M. perpusilla extract showed the highest phenolic content and the lowest being in $N$. herpeticum. While the flavonoid content varied from $0.23 \pm 0.1$ to $1.66 \pm 0.1 \mathrm{mg}$ QE/g DE, the highest being in M. perpusilla extract and the lowest being in S. zeylanica. It is seen from the results (Table 5) that the total phenolic content is higher than the flavonoid content. The total phenolic content of selected wild edible plants reported by Wong et al. [35] ranged from 0.69 to $19.65 \mathrm{mg} \mathrm{GAE} / \mathrm{g}$ dried weight and the flavonoid content from $0.19 \pm 0.02$ to $8.37 \pm 2.62 \mathrm{mg}$ catechin equivalent per gram of dried weight. Xia et al. [36] reported higher phenolic contents in six edible wild plants that ranged from $278.7 \pm 24.4$ to $417.3 \pm 38.3 \mathrm{mg}$ GAE/g dried weight. Saikia et al. [37] reported phenolic content in some non-conventional green leafy vegetables of North-East India that ranged from $4.62-14.74 \mathrm{mg} \mathrm{GAE} / \mathrm{g}$ dry weight and flavonoid content varying from $0.65-7.72 \mathrm{mg} \mathrm{QE} / \mathrm{g}$ dry weight. $\mathrm{Ng}$ et al. [27] also reported phenolic content 
of selected tropical wild vegetables that ranged from 1.8 to $4.1 \mathrm{mg} \mathrm{GAE} / \mathrm{g}$ fresh weight and flavonoid content varied from 0.4 to $1.4 \mathrm{mg}$ rutin equivalents/g fresh weight.

Phenolic compounds are secondary metabolites and widely distributed in plants. Natural antioxidants are generally derived from plants in the form of phenolic compounds such as phenolic acids, flavonoids, tocopherols etc. Phenolics are essential components of many vegetables and fruits not only for their major influence on physical qualities of the vegetables and fruits like color, flavor, and taste, but also for their antioxidant, anticarcinogenic, antimicrobial, antiallergic, antimutagenic, and anti-inflammatory properties [38]. Several literatures have revealed that the antioxidant activity of phenolic compounds is due to their redox properties, hydrogen donating abilities, and singlet oxygen quenchers $[3,25]$. Therefore, they have important roles in decreasing the risk of many human diseases. Flavonoids which are known as secondary natural metabolites are a group of phenolic compounds and free radical scavengers which prevent oxidative cell damage through their water soluble property and also possess anti-cancer, antimicrobial, antithrombotic, and antimutagenic activities [8, 34, 39].

The vitamin C content (Table 5) varied from $15.24 \pm 1.650$ to $85.71 \pm 5.710 \mathrm{mg} / 100 \mathrm{~g}$ of fresh weight and was detected highest in $N$. herpeticum $(85.71 \pm 5.710 \mathrm{mg} / 100 \mathrm{~g})$ followed by M. perpusilla $(57.07 \pm 1.59 \mathrm{mg} / 100 \mathrm{~g})$ and S. zeylanica $(40.37 \pm 1.626 \mathrm{mg} / 100 \mathrm{~g})$ and the lowest being in S. peguensis $(15.24 \pm 1.650 \mathrm{mg} / 100 \mathrm{~g})$. Similarly, the vitamin $C$ content in some wild edible plants reported by Narzary et al. [23] ranged from $11.39 \pm 0.0002$ to $79.06 \pm 0.02 \mathrm{mg} / 100 \mathrm{~g}$ fresh weight which is close to the values of present report. Vitamin $\mathrm{C}$ is also known as ascorbic acid and it the main vitamin provided by fruits and vegetables in the human diet. Fruits and vegetables generally can supply about $90 \%$ of a person's dietary vitamin C requirement. The average vitamin C requirement for an adult human being is about $70 \mathrm{mg}$ per day. Vitamin $\mathrm{C}$ is required during various growth stages of human life and being a powerful reducing agent, it plays an essential role in absorbing and deactivating free radicals and thus protects the body from harmful effects [10, 40].

In this study, more than one assay was used to investigate antioxidant activity of plant extracts because of the more complex nature of phytochemicals that may reveal several mechanisms of antioxidant action. M. perpusilla revealed strong antioxidant activity among the six wild edible plants. It is interesting that M. perpusilla methanol extract which showed the highest FRAP value, highest phenolic and flavonoid contents (Table 5) also exhibited the strongest DPPH radical scavenging activity (Table 4). Olszewska et al. [41] reported that there is a high correlation between phenolic compounds and antioxidant activity, and the phenolic compounds are the main constituents for the antioxidant property. Xia et al. [36] reported that plant having the highest phenolic content showed the similar ability to scavenge DPPH free radical and similar reducing power. Samappito et al. [42] also reported in their work that the sample with the highest amount of phenolics had a very high level of scavenging activity. The consumption of plant foods with high content polyphenols can lessen the risk of heart disease by slowing the development of atherosclerosis due to their antioxidant properties [43, 44].

\subsection{Pearson's correlation}

Pearson's correlation study of the plant species showed that FRAP assay is strongly correlated with TPC and TFC, and TPC also displayed a strong positive correlation with TFC significantly at $p<0.01$ (Table 6). A strong positive correlation of FRAP assay with TPC and TFC was also reported by Islary et al. [45] which is in agreement with this study. Moreover, this study also presented a positive correlation of DPPH assay with ABTS and Vitamin $\mathrm{C}$, ABTS assay with $\mathrm{H}_{2} \mathrm{O}_{2}$, FRAP assay with Vitamin C, and TPC with Vitamin C. Similar types of reports on some wild plants and fruits from Assam of North-East India were also presented by Narzary et al. [3] and Islary et al. [12].

\section{Conclusion}

The investigation revealed that all the six wild edible plants have variable quantities of proximate composition and mineral contents. The phytochemical analysis showed the presence of many medicinally active secondary 
Table 6

Pearson's correlation coefficients of antioxidant activity (DPPH, ABTS, $\mathrm{H}_{2} \mathrm{O}_{2}$, FRAP), TPC, TFC and vitamin C in the plant species

\begin{tabular}{|c|c|c|c|c|c|c|c|}
\hline & DPPH & ABTS & $\mathrm{H}_{2} \mathrm{O}_{2}$ & FRAP & TPC & TFC & Vitamin $\mathrm{C}$ \\
\hline DPPH & 1 & & & & & & \\
\hline ABTS & 0.412 & 1 & & & & & \\
\hline $\mathrm{H}_{2} \mathrm{O}_{2}$ & -0.164 & 0.055 & 1 & & & & \\
\hline FRAP & -0.559 & -0.298 & -0.344 & 1 & & & \\
\hline TPC & -0.640 & -0.131 & -0.236 & $0.969^{\mathrm{a}}$ & 1 & & \\
\hline TFC & -0.660 & -0.238 & -0.455 & $0.947^{\mathrm{a}}$ & $0.947^{\mathrm{a}}$ & 1 & \\
\hline Vitamin C & 0.606 & -0.077 & -0.279 & 0.220 & 0.059 & -0.033 & 1 \\
\hline
\end{tabular}

${ }^{\text {a }}$ Correlation is significant at $p<0.01$.

metabolites. Methanol extracts of the plants exhibited good antioxidant properties with the strongest activity in Melothria perpusilla. The analyses of phenolic, flavonoid, and vitamin $\mathrm{C}$ contents established the food values of plants which are associated to free radical scavenging activities. Hence, the plants could be good sources of nutritional value and natural antioxidants in improving malnutrition problems, combating many human deficiency diseases and could also be developed as drugs for the prevention and treatment of diseases especially caused by oxidative stress.

\section{Acknowledgments}

The authors are thankful to the University Grants Commission, New Delhi, for the award of RGN-JRF to HN, the Botanical Survey of India, Shillong for identification of plants and the Department of Food Engineering and Technology, Central Institute of Technology, Kokrajhar for providing necessary facilities for this study.

\section{Conflict of interest}

None to report.

\section{References}

[1] Islam MZ, Hoque MM, Asif-Ul-Alam SM, Monalisa K. Chemical composition, Antioxidant capacities and storage stability of Citrus macroptera and Garcinia pedunculata fruits. Emir J Food Agri. 2015;27(3):275-82.

[2] Saha J, Biswal AK, Deka SC. Chemical composition of some underutilized green leafy vegetables of Sonitpur district of Assam, India. Int Food Res J. 2015;22(4):1466-73.

[3] Narzary H, Islary A, Basumatary S. Phytochemicals and antioxidant properties of eleven wild edible plants from Assam, India. Mediterranean J Nutr Metabol. 2016;9(3):191-201.

[4] Hadbaoui Z, Djeridane A, Yousfi M, Saidi M, Nadjemi B. Fatty acid, tocopherol composition and the antioxidant activity of the lipid extract from the sorghum grains growing in Algeria. Mediterranean J Nutr Metabol. 2010;3:215-20.

[5] Giampieri F, Forbes-Hernandez TY, Gasparrini M, Afrin S, Cianciosi D, Reboredo-Rodriguez P, Varela-Lopez A, Quiles JL, Mezzetti B, Battino M. The healthy effects of strawberry bioactive compounds on molecular pathways related to chronic diseases. Ann NY Acad Sci. 2017;1-10. DOI: 10.1111/nyas.13373

[6] Chipurura B, Muchuweti M, Kasiyamhuru A. Wild leafy vegetables consumed in Buhera district of Zimbabwe and their phenolic compounds content. Ecol Food Nutr. 2013;52:178-89.

[7] Zineb G, Boukouada M, Djeridane A, Saidi M, Yousfi M. Screening of antioxidant activity and phenolic compounds of various date palm (Phoenix dactylifera) fruits from Algeria. Mediterranean J Nutr Metabol. 2012;5:119-26. 
[8] Priora RL, Sintarab M, Chang T. Multi-radical (ORAC $\left.\mathrm{MR}_{5}\right)$ antioxidant capacity of selected berries and effects of food processing. J Berry Res. 2016;6:159-73.

[9] Nazeer RA, Naqash SY. In vitro antioxidant activity of two molluscs, Loligo duvauceli Orbigny and Donax cuneatus Linnaeus, by solvent extraction methods. Mediterranean J Nutr Metabol. 2013;6:17-21.

[10] Islary A, Sarmah J, Basumatary S. Proximate composition, mineral content, phytochemical analysis and in vitro antioxidant activities of a wild edible fruit (Grewia sapida Roxb. ex DC.) found in Assam of North-East India. J Invest Biochem. 2016;5(1): 21-31.

[11] Naqvi SAR, Mahmood N, Naz S, Hussain Z, Sherazi TA, Khan ZA, Shahzad SA, Yar M, Bukhari IH, Ahmad M, Mansha A. Antioxidant and antibacterial evaluation of honey bee hive extracts using in vitro models. Mediterranean J Nutr Metabol. 2013;6:247-53.

[12] Islary A, Sarmah J, Basumatary S. Nutritional value, phytochemicals and antioxidant properties of two wild edible fruits (Eugenia operculata Roxb. and Antidesma bunius L.) from Assam, North-East India. Mediterranean J Nutr Metabol. 2017;10(1):29-40.

[13] Awad NE, Seida AA, Hamed MA, Mahmoud AH, Elbatanony MM. Phytochemical and in vitro screening of some Ficus and Morus spp. for hypolipidaemic and antioxidant activities and in vivo assessment of Ficus mysorensis (Roth). Natural Prod Res. 2012;26(12): 1101-11.

[14] Kumar SA, Muthuselvam M. Analysis of phytochemical constituents and antimicrobial activities of Aloe vera L. against clinical pathogens. World J Agric Sci. 2009;5(5):572-6.

[15] WHO. Quality Control Methods for Medicinal Plant Materials. 1998;62-3.

[16] WHO. WHO Drug Information. 2005;19(3):215-6.

[17] Garg RM. Screening of Indian withania plant and marketed products for trace elements, heavy metals for quality and efficacy. J Pharmacog Phytochem. 2014;2(5):66-8.

[18] Ramadan MAE, Al-Ashkar EA. The effect of different fertilizers on the heavy metals in soil and tomato plant. Austr J Basic Appl Sci. 2007;1(3):300-6.

[19] Singh NM, Singh NR. A quantitative analysis of heavy metals in vegetables grown at Kakching-Wabagai area, Thoubal District Manipur. PARIPEX-Indian J Res. 2014;3(6):1-3.

[20] Gnansounou SM, Noudogbessi JP, Yehouenou B, Gbaguidi ANM, Dovonon L, Aina MP, Ahissou H, Sohounhloue D. Proximate composition and micronutrient potentials of Dialium guineense wild growing in Benin. Int Food Res J. 2014;21(4):1603-7.

[21] Narzary H, Basumatary S. Determination of mineral composition of some wild edible plants consumed by Bodos of Assam, North-East India. J Chem Pharm Res. 2017;9(5):60-4.

[22] Ajasa MA, Bello OM, Ogunwande AI, Olawore ON. Heavy trace metals and macronutrient status in herbal plants of Nigeria. Food Chem. 2004;85:67-71.

[23] Narzary H, Swargiary A, Basumatary S. Proximate and vitamin C analysis of wild edible plants consumed by Bodos of Assam, India. J Mol Pathophysiol. 2015;4(4):128-33.

[24] AOAC. Official Methods of Analysis. 17th ed. Inc. Virginia, USA: Association of Official Analytical Chemists. 2000.

[25] Arunachalam K, Murugan R, Parimelazhagan T. Evaluation of antioxidant activity, and nutritional and chemical composition of Ficus amplissima Smith fruit. Int J Food Properties. 2014;17:454-68.

[26] Bello MO, Asubonteng K, Sodamade A, Adeniyi S. Nutrient potentials of two lesser known leafy vegetables (Vitex doniana L. and Sesamum indicum L. Int Food Res J. 2014;21(5):1993-9.

[27] $\mathrm{Ng} \mathrm{XN}$, Chye FY, Ismail AM. Nutritional profile and antioxidative properties of selected tropical wild vegetables. Int Food Res J. 2012;19(4):1487-96.

[28] Aberoumand A, Deokule SS. Determination of elements profile of some wild edible plants. Food Anal Method. 2009;2:116-9.

[29] Pandey G, Jain GC, Mathur N. Therapeutic potential of metals in managing diabetes mellitus: A review. J Mol Pathophysiol. 2012;1(1):63-76.

[30] Sajib MAM, Jahan S, Islam MZ, Khan TA, Saha BK. Nutritional evaluation and heavy metals content of selected tropical fruits in Bangladesh. Int Food Res J. 2014;21(2):609-15.

[31] Salama AK, Radwan MA. Heavy metals $(\mathrm{Cd}, \mathrm{Pb})$ and trace elements $(\mathrm{Cu}, \mathrm{Zn})$ contents in some foodstuffs from the Egyptian market. Emir J Agric Sci. 2005;17(1):34-42.

[32] Zhang A, Fang Y, Wang H, Li H, Zhang Z. Free-radical scavenging properties and reducing power of grape cane extracts from 11 selected grape cultivars widely grown in China. Molecules. 2011;16:10104-22.

[33] Fu L, Xu BT, Xu XR, Qin XS, Gan RY, Li HB. Antioxidant capacities and total phenolic contents of 56 wild fruits from South China. Molecules. 2010;15:8602-17.

[34] Niki E. Antioxidant capacity: Which capacity and how to assess it? J Berry Res. 2011;1:169-76.

[35] Wong JY, Matanjun P, Ooi YBH, Chia KF. Evaluation of antioxidant activities in relation to total phenolics and flavonoids content of selected Malaysian wild edible plants by multivariate analysis. Int J Food Properties. 2014;17:1763-78. 
[36] Xia DZ, Yu XF, Zhu ZY, Zou ZD. Antioxidant and antibacterial activity of six edible wild plants (Sonchus spp.) in China. Natural Prod Res. 2011;25(20):1893-1901.

[37] Saikia P, Deka DC. Antioxidant activity of some non-conventional green leafy vegetables of North-East India. Mediterranean J Nutr Metabol. 2015;8:205-11.

[38] Najafabad AM, Jamei R. Free radical scavenging capacity and antioxidant activity of methanolic and ethanolic extracts of plum (Prunus domestica L.) in both fresh and dried samples. Avicenna J Phytomed. 2014;4(5):343-53.

[39] Yao LH, Jiang YM, Shi J, Tomás-Barberán FA, Datta NN, Singanusong R, Chen SS. Flavonoids in food and their health benefits. Plant Foods Hum Nutr. 2004;59:113-22.

[40] Khomdram S, Barthakur S, Devi GS. Biochemical and molecular analysis of wild endemic fruits of the Manipur region of India. Int J Fruit Sci. 2014;14:1-14.

[41] Olszewska MA, Michel P. Antioxidant activity of inflorescences, leaves and fruits of three Sorbus species in relation to their polyphenolic composition. Natural Prod Res. 2009;23(16):1507-21.

[42] Samappito S, Butkhup L. Analysis of anthocyanin, flavonoids, and phenolic acid contents of ten fruits and antioxidant activity. Int J Fruit Sci. 2010;10:264-80.

[43] Visioli FBL, Galli C. Diet and prevention of coronary heart disease: The potential role of phytochemicals. Cardiovas Res. 2000;47(3):419-25.

[44] Chiva-Blancha G, Visioli F. Polyphenols and health: Moving beyond antioxidants. J Berry Res. 2012;2:63-71.

[45] Islary A, Sarmah J, Basumatary S. Nutritional properties, phytochemicals and in vitro antioxidant assessment of two wild edible fruits from Assam of North-East India. J Pharm Nutr Sci. 2017;7(2):55-63. 